\title{
FRATURA FACIAL EM PACIENTE PEDIÁTRICO
}

Renato Alcantara NERI, Wesley Santos CONRADO, Eduardo MORESCHI, Vilmar Divanir GOTTARDO

As fixações ósseas internas na região crânio-maxilo-facial podem ser realizadas por fios de aço, placas metálicas em titânio, por parafusos interfragmentários e por placas bioabsorvíveis. Estes materiais são compostos de ácido poliláctico e de ácido poliglicólico, que mantêm adequada resistência por tempo superior ao necessário para a formação do calo ósseo, com indicação de emprego em cirurgias de fraturas em terço médio da face e, aquelas reconstrutivas do esqueleto crânio-maxilo-facial. Esta técnica foi desenvolvida para evitar uma segunda intervenção, que por vezes se faz necessária para retirada do material metálico. O presente trabalho objetivou a descrição de um caso clínico de fratura facial tratada com o sistema de placas reabsorvíveis. Paciente de 2 anos de idade, leucoderma, gênero feminino, vítima de acidente automobilístico com traumatismo na região de sínfise mandibular. Ao exame físico observou mordida aberta anterior, limitação de abertura bucal, maloclusão e desvio mandibular na abertura bucal. Exames imaginológicos constataram fraturas mandibulares localizadas na região de sínfise mandibular e processo condilar bilateralmente. Sendo assim, optou-se pela cirurgia reconstrutiva utilizando mini-placa e parafusos reabsorvíveis. No pós-operatório de 1 ano, concluímos que o sistema de placas bioabsorvíveis constituem uma interessante forma de fixação de fraturas faciais, em especial nos pacientes pediátricos.

Palavras-Chave: Crânio; Maloclusão; Ácido Poliglicólico. 